quantile-quantile plots of $p$-values

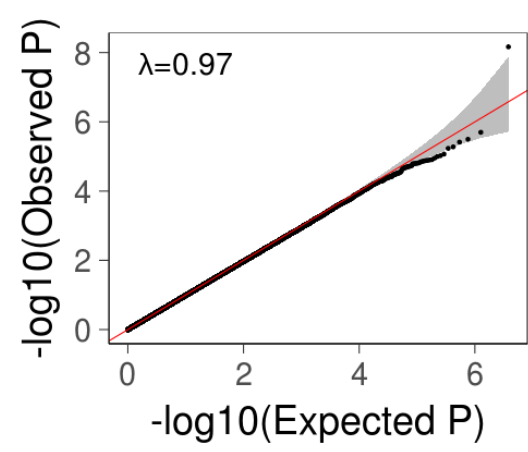

SNP

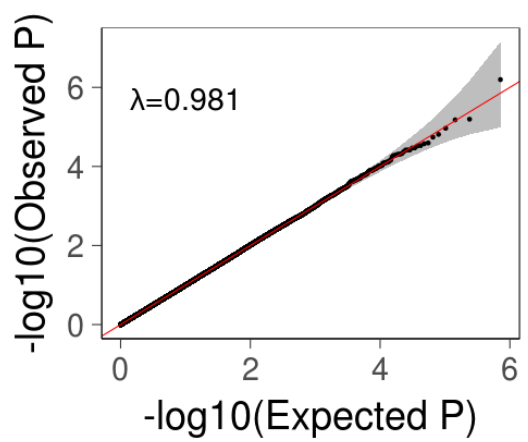

INDEL

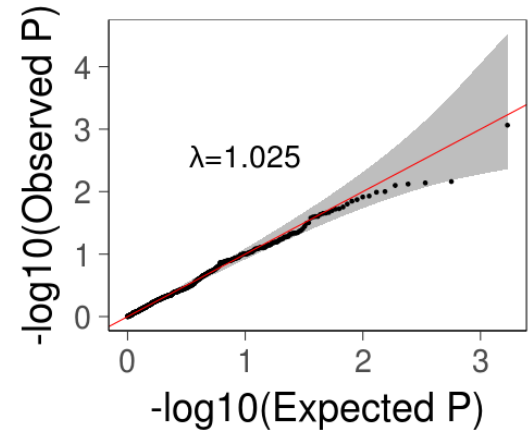

ORF

\title{
SNP results
}

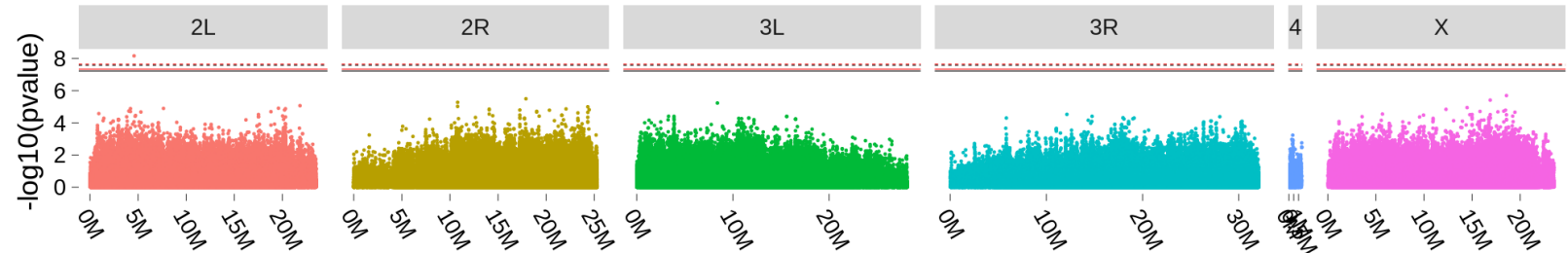

\begin{tabular}{ccccccc}
\hline Peak rank & Chr & SNP pos(bp) & $-\log 10($ pvalue $)$ & Candidate gene ID & Candidate gene name & Distance to gene(bp) \\
\hline 1 & 2L & 4583403 & 8.165522 & NA & NA
\end{tabular}

INDEL results

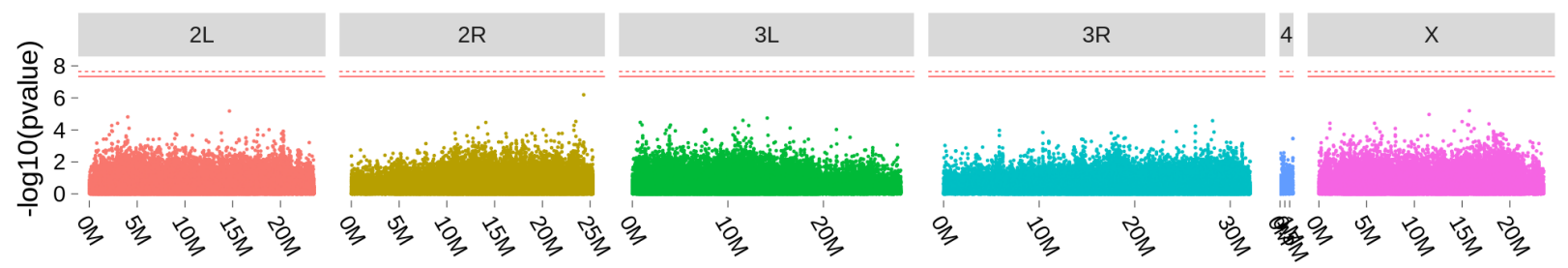

\section{ORFS results}

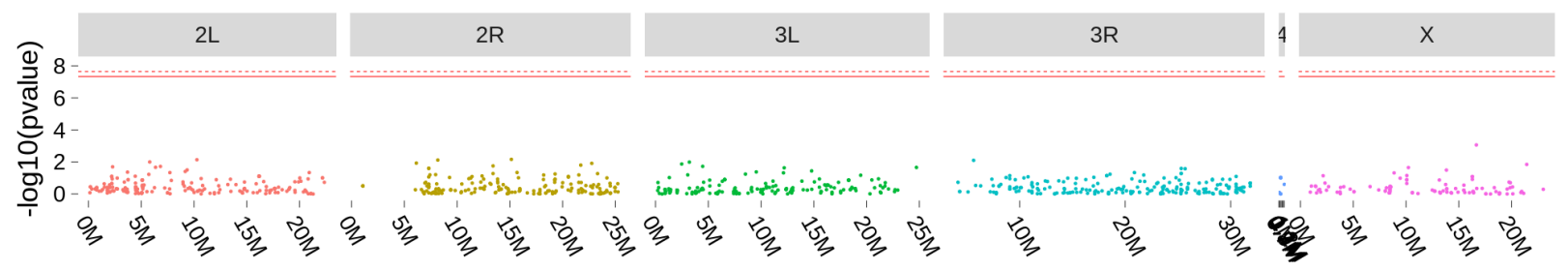

